\title{
Exploration of Obesity Status of Indonesia Basic Health Research 2013 With Synthetic Minority Over-Sampling Techniques*
}

\author{
Eksplorasi Status Obesitas Riset Kesehatan Dasar 2013 Indonesia \\ dengan Teknik Synthetic Minority Over-Sampling
Sri Astuti Thamrin ${ }^{1 \ddagger}$, Dian Sidik², Hedi Kuswanto ${ }^{1}$, Armin Lawi $^{3}$, and Ansariadi $^{2}$

\author{
${ }^{1}$ Departemen Statistika, Universitas Hasanuddin, Indonesia \\ ${ }^{2}$ Departemen Epidemiologi, Universitas Hasanuddin, Indonesia \\ ${ }^{3}$ Departemen Matematika, Universitas Hasanuddin, Indonesia \\ ‡corresponding author: tuti@unhas.ac.id
}

Copyright $@ 2021$ Sri Astuti Thamrin, Dian Sidik, Hedi Kuswanto, Armin Lawi, and Ansariadi. This is an open-access article distributed under the Creative Commons Attribution License, which permits unrestricted use, distribution, and reproduction in any medium, provided the original work is properly cited.

\begin{abstract}
The accuracy of the data class is very important in classification with a machine learning approach. The more accurate the existing data sets and classes, the better the output generated by machine learning. In fact, classification can experience imbalance class data in which each class does not have the same portion of the data set it has. The existence of data imbalance will affect the classification accuracy. One of the easiest ways to correct imbalanced data classes is to balance it. This study aims to explore the problem of data class imbalance in the medium case dataset and to address the imbalance of data classes as well. The Synthetic Minority Over-Sampling Technique (SMOTE) method is used to overcome the problem of class imbalance in obesity status in Indonesia 2013 Basic Health Research (RISKESDAS). The results show that the number of obese class (13.9\%) and non-obese class (84.6\%). This means that there is an imbalance in the data class with moderate criteria. Moreover, SMOTE with oversampling $600 \%$ can improve the level of minor classes (obesity). As consequence, the classes of obesity status balanced. Therefore, SMOTE technique was better compared to without SMOTE in exploring the obesity status of Indonesia RISKESDAS 2013.
\end{abstract}

Keywords: Imbalanced data, machine learning, obesity status, SMOTE.

\footnotetext{
${ }^{*}$ Received: Nov 2020; Reviewed: Mar 2021; Published: Mar 2021
} 


\section{Pendahuluan}

Obesitas dapat terjadi karena adanya ketidakseimbangan jumlah makanan yang masuk dibandingkan dengan pengeluaran energi yang dilakukan oleh tubuh ([RISKESDAS], 2013). Di Asia Tenggara, jumlah kasus penderita kasus gizi buruk dan gizi kurang masih cukup tinggi tetapi jumlah kasus kegemukan dan obesitas semakin meningkat (ASEAN / UNICEF / WHO Regional Report, 2016). Di Indonesia, angka prevalensi obesitas terus mengalami peningkatan khususnya pada wanita dewasa. Dari tahun 2007 dan 2010, angka prevalensi obesitas pada wanita dewasa masingmasing sebesar 14,8\%, 15,5\% dan meningkat tajam sebesar 32,9\% pada tahun 2013. Sementara, laki-laki dewasa mengalami obesitas pada tahun 2007 sebanyak 13,9\%, kemudian sedikit menurun ke angka 7,8\% pada tahun 2010 dan meningkat Ig pada tahun 2013 sebesar 19,7\%. ([KEMENKES RI], 2014). Oleh karena itu penting untuk di eksplorasi data status obesitas di Indonesia.

Status obesitas dapat dieksplorasi dengan menggunakan teknik pembelajaran mesin (machine learning). Dalam klasifikasi pada pembelajaran mesin, akurasi dari kelas data sangat penting (Ente et al., 2020; Selya \& Anshutz, 2018; Witten et al., 2011). Indikator luaran yang baik dari pembelajaran mesin dapat dilihat dari akurasi dataset dan kelas yang ada. Dataset akurat dicapai jika kelas data tidak mengalami ketidakseimbangan.

Masalah ketidakseimbangan data (Branco et al., 2016; Krawczyk, 2016; Sun et al., 2009) terjadi dalam tugas klasifikasi setiap kali jumlah pengamatan milik salah satu kelas, kelas mayoritas, melebihi jumlah pengamatan milik salah satu kelas lain, kelas minoritas. Algoritma klasifikasi tradisional rentan terhadap keberadaan data yang tidak seimbang, dan cenderung menampilkan bias terhadap kelas mayoritas dengan mengorbankan kemampuan diskriminasi kelas minoritas. Efek negatif pada kinerja klasifikasi ini diperburuk oleh adanya faktor kesulitan dataset tambahan, seperti disjungsi kecil (Jo \& Japkowicz, 2004) atau jumlah observasi data latih yang tidak mencukupi (Chen \& Wasikowski, 2008), yang dapat menyebabkan model over-fitting.

Data tidak seimbang dapat diatasi dengan tiga pendekatan (Yap et al., 2014), yaitu pendekatan pada level data, classifier dan ensemble. Teknik over-sampling dan undersampling digunakan pada pendekatan level data. Selain itu, pada pendekatan level data ini, kecondongan distribusi kelas data dapat diperbaiki melalui data buatan (synthetic). Pada level data ini dapat digunakan metode SMOTE (Synthetic Minority Over-sampling Technique) (N. V. Chawla et al., 2002). Pendekatan level classifier berfokus pada pengklasifikasi (classifier) kelas minoritas menggunakan operasi algoritma (Zhang et al., 2011). Kemudian, pendekatan ensemble dilakukan perbaikan algoritma pengklasifikasi.

SMOTE merupakan algoritma dengan pendekatan over-sampling yaitu data buatan untuk kelas data minoritas dibangkitkan agar terjadi keseimbangan proporsi kelas data mayor dan minor (Alghamdi et al., 2017; N. V. Chawla et al., 2002; Mustaqim et al., 2019). Keuntungan dari pendekatan ini adalah mampu mengatasi masalah ketidakseimbangan data kelas karena sejumlah data buatan ditambahkan pada kelas minoritas yang membuat distribusi data dalam kelas menjadi seimbang. Ada tiga kasus ketidakseimbangan kelas data yaitu ringan (20-40\%), sedang (1-20\%), dan ekstrem $(<1 \%)$; bergantung pada proporsi kelas minoritas ke seluruh kumpulan data. Oleh karena itu dalam studi ini akan dieksplorasi masalah ketidakseimbangan data kelas 
untuk kasus dataset sedang dan mengatasi ketidakseimbangan data kelas dari status obesitas Survei Riset Kesehatan Dasar (RISKESDAS) 2013 Indonesia.

\section{Metodologi}

\section{$2.1 \quad$ Sumber Data}

Dalam studi ini digunakan dataset obesitas Indonesia yang diperoleh dari Survei RISKESDAS 2013 Indonesia. Data tersebut dapat di akses melalui proses permintaan data di Kementerian Kesehatan (https://www.litbang.kemkes.go.id/). Dataset ini terdiri dari dua status yaitu obesitas dan tidak obesitas dengan 25 variabel dan 69 atribut. Semua variabel dalam bentuk kategorik dengan jumlah data sebanyak 722.329 responden. Adapun fitur data yang hilang (missing) atau yang mengandung "NA" dikeluarkan dari analisis. Dalam pengolahan data ini digunakan perangkat lunak $R$ versi 3.5.1.

\subsection{Pre-processing Data}

Pada tahap pre-processing ini dilakukan penyaringan data untuk memilih data yang mempunyai nilai atau memilih data sesuai dengan kebutuhan. Pada data obesitas, fungsi filter digunakan pada variabel $Y$ (status obesitas) dan variabel Hamil. Pada variabel status obesitas terdapat 9.749 data dengan nilai "NA" yang difilter dari 722.329 menjadi 712.580 data. Selanjutnya pada variabel Hamil terdapat 7.603 data dengan nilai "NA" difilter dari 712.580 data menjadi 704.977 data. Jadi jumlah data yang di analisis adalah 704.977 data.

Mengatasi masalah tingginya dimensi suatu data, dapat dilakukan dengan seleksi variabel. Dalam studi ini, pendekatan filter Chi-Square $\left(\chi^{2}\right)$ digunakan. Pengujian hipotesis pada uji Chi-Square $\left(\chi^{2}\right)$ menggunakan taraf nyata $(\alpha)$ sebesar $5 \%$. Dalam dua kelas, uji untuk hipotesis nol $\left(\mathrm{H}_{0}\right)$ menunjukkan bahwa rata-rata dari kelas satu dan dua adalah sama. Ini berarti bahwa tidak ada perbedaan signifikan kedua ratarata tersebut, sehingga variabel tersebut tidak banyak berkontribusi dalam klasifikasi. Variabel yang memiliki kesamaan yang signifikan dapat dikeluarkan, dan variabel yang memiliki perbedaan signifikan dapat diterima. Dalam studi ini uji Chi-square akan diterapkan pada setiap variabel, dan diukur nilai $p$-value yang sesuai. Variabel yang paling informatif akan diidentifikasi dengan menyortir masing-masing variabel ( $p$-value $<0,05)$.

\subsection{Teknik Synthetic Minority Over-sampling}

Salah satu metode yang dapat digunakan dalam menangani pengaruh dari sedikitnya informasi mengenai kelas minoritas dalam suatu gugus data adalah Synthetic Minority Over-sampling Technique (SMOTE). Metode ini diperkenalkan oleh N. V. Chawla dkk., (2002). SMOTE merupakan algoritma dengan pendekatan over-sampling yaitu menambah jumlah data pengamatan pada kelas minoritas (N. V. Chawla, 2005; Zhu et al., 2017).

Teknik SMOTE ini dapat digunakan dalam penanganan data tidak seimbang. Data buatan untuk kelas data minoritas dibangkitkan untuk menyeimbangkan proporsi kelas data mayor dan minor (Alghamdi et al., 2017). Dalam membangkitkan data buatan 
tersebut, k-tetangga terdekat ( $k$-nearest neighbor) digunakan (N. V. Chawla et al., 2002). Pada studi ini, teknik SMOTE dilakukan dengan cara menghitung jarak antar sampel kelas minornya. Jarak antar sampel minor ini dilakukan dengan metode Modify Value Difference Metric (MVDM) (Cost \& Salzberg, 1993). Adapun langkahlangkahnya adalah sebagai berikut:

a. Menghitung jarak antara dua amatan yang berskala nominal menggunakan MVDM dengan formula sebagai berikut:

$$
\Delta(\mathrm{x}, \mathrm{y})=\mathrm{w}_{\mathrm{x}} \mathrm{w}_{\mathrm{y}} \sum_{\mathrm{i}=1}^{\mathrm{N}} \delta\left(\mathrm{v}_{1 \mathrm{i}}, \mathrm{v}_{2 \mathrm{i}}\right) \text {, }
$$

dimana $\Delta(\mathrm{x}, \mathrm{y})$ adalah jarak antara amatan $\mathrm{x}$ dan $\mathrm{y}, \mathrm{w}_{\mathrm{x}}$ adalah bobot amatan $\mathrm{x}$ (dapat diabaikan), $\mathrm{w}_{\mathrm{y}}$ adalah bobot amatan y (dapat diabaikan), $\mathrm{N}$ adalah banyaknya variabel penjelas. Kemudian $\delta\left(\mathrm{v}_{1 \mathrm{i}} \mathrm{v}_{2 \mathrm{i}}\right)$ adalah jarak antara amatan $\mathrm{x}$ dan y pada variabel ke-i dengan perhitungan jarak antar amatan $x$ dan y pada variabel ke-i dilakukan melalui:

$$
\delta\left(\mathrm{v}_{1 \mathrm{i}}, \mathrm{v}_{2 \mathrm{i}}\right)=\sum_{\mathrm{j}=1}^{\mathrm{S}}\left|\frac{\mathrm{C}_{1 \mathrm{j}}}{\mathrm{C}_{1}}-\frac{\mathrm{C}_{2 \mathrm{j}}}{\mathrm{C}_{2}}\right|^{\mathrm{k}} \text {, }
$$

dimana $\mathrm{S}$ adalah banyaknya kelas pada variabel respon, $\mathrm{C}_{\mathrm{xj}}$ adalah banyaknya kategori $x$ pada kelas ke-j, $C_{y j}$ adalah banyaknya kategori y pada kelas ke-j, $C_{x}$ adalah banyaknya kategori $\mathrm{x}$ terjadi, $\mathrm{C}_{\mathrm{y}}$ adalah banyaknya kategori y yang terjadi dan $\mathrm{k}$ adalah konstanta (biasanya bernilai 1 ).

b. Untuk nilai yang bersifat nominal, kategori mayoritas yang dipilih adalah kategori yang letaknya antara amatan kelas minoritas dengan k-tetangga terdekatnya. Jika nilainya sama maka dipilih secara acak.

c. Nilai yang terpilih tersebut merupakan amatan yang baru.

Dalam studi ini, teknik SMOTE dengan $350 \%$, $600 \%$, over-sampling $250 \%$ dan under-sampling $150 \%$ digunakan untuk menghasilkan tiga dataset baru.

\section{Hasil dan Pembahasan}

Gambaran umum tentang variabel penjelas data obesitas di Indonesia pada Survei RISKESDAS 2013 disajikan pada Tabel 1. Pada Tabel 1, dari 722.329 status obesitas di Indonesia, sebanyak $101.023(13,99 \%)$ orang mengalami obesitas, 611.557 $(84,66 \%)$ orang tidak mengalami obesitas dan sebanyak $9.749(1,32 \%)$ orang tidak diketahui status obesitasnya. Pada Tabel 1 ini juga terlihat jumlah kelas obesitas dan tidak obesitas terlihat tidak seimbang dengan ketidakseimbangan kelas data berada pada kriteria sedang.

Tabel 1: Gambaran umum tentang data status obesitas RISKESDAS 2013 di Indonesia

\begin{tabular}{lcc}
\hline \multicolumn{1}{c}{ Status Obesitas } & Frekuensi & Persentasi \\
\hline Obesitas & 101.023 & $13,99 \%$ \\
Tidak obesitas & 611.557 & $84,66 \%$ \\
"NA" & 9.749 & $1,32 \%$ \\
\hline \multicolumn{1}{c}{ Jumlah } & 722.329 & $100 \%$ \\
\hline
\end{tabular}


Banyaknya variabel pada data akan menimbulkan masalah pada tahap pengolahan data. Dalam tahapan ini, seleksi variabel dilakukan dengan menggunakan metode Chi-Square $\left(\chi^{2}\right)$. Dari hasil seleksi variabel diketahui bahwa terdapat 11 variabel yang dipilih untuk di analisis $(p$-value $<0,01)$. Tabel 2 memperlihatkan karakteristik data status obesitas Survei RISKESDAS 2013 Indonesia sebelum dilakukan penyeimbangan data kelas berdasarkan variabel.

Tabel 2: Karakteristik Status obesitas RISKESDAS 2013 di Indonesia tanpa menggunakan teknik SMOTE

\begin{tabular}{|c|c|c|c|}
\hline \multirow[b]{2}{*}{ Variabel dan Atribut } & \multicolumn{2}{|c|}{ Status obesitas } & \multirow[t]{2}{*}{ Total } \\
\hline & Obesitas & $\begin{array}{c}\text { Tidak } \\
\text { obesitas }\end{array}$ & \\
\hline \multicolumn{4}{|l|}{ Jenis kelamin $(\mathrm{X} 1)$} \\
\hline Laki-laki & 31.724 & 311.270 & 342.994 \\
\hline Perempuan & 67.391 & 294.592 & 361.983 \\
\hline Total & 99.115 & 605.862 & 704.977 \\
\hline \multicolumn{4}{|l|}{ Umur (X2) } \\
\hline 15 - 34 Tahun & 25.475 & 257.554 & 283.029 \\
\hline 35 - 54 Tahun & 56.830 & 231.286 & 288.116 \\
\hline 55 - 74 Tahun & 16.015 & 102.429 & 118.444 \\
\hline 75 - 94 Tahun & 789 & 14.357 & 15.146 \\
\hline 95 - 114 Tahun & 6 & 233 & 239 \\
\hline $115-134$ Tahun & 0 & 3 & 3 \\
\hline Total & 99.115 & 605.862 & 704.977 \\
\hline \multicolumn{4}{|l|}{ Merokok (X3) } \\
\hline Ya & 19.543 & 203.348 & 222.891 \\
\hline Tidak & 79.572 & 402.514 & 482.086 \\
\hline Total & 99.115 & 605.862 & 704.977 \\
\hline \multicolumn{4}{|l|}{ Aktifitas Berat (X4) } \\
\hline Ya & 29.905 & 246.243 & 276.148 \\
\hline Tidak & 69.210 & 359.619 & 428.829 \\
\hline Total & 99.115 & 605.862 & 704.977 \\
\hline \multicolumn{4}{|l|}{ Aktifitas Sedang (X5) } \\
\hline Ya & 88.970 & 518.483 & 607.453 \\
\hline Tidak & 10.145 & 87.379 & 97.524 \\
\hline Total & 99.115 & 605.862 & 704.977 \\
\hline \multicolumn{4}{|l|}{ Makan Buah (X6) } \\
\hline Tidak Pernah & 10.316 & 85.930 & 96.246 \\
\hline Satu Hari & 19.247 & 143.388 & 162.635 \\
\hline Dua Hari & 19.444 & 127.304 & 146.748 \\
\hline Tiga Hari & 20.753 & 119.217 & 139.970 \\
\hline Empat Hari & 7.409 & 41.661 & 49.070 \\
\hline Lima Hari & 3.871 & 20.177 & 24.048 \\
\hline Enam Hari & 1.630 & 7.988 & 9.618 \\
\hline
\end{tabular}




\begin{tabular}{|c|c|c|c|}
\hline \multirow[b]{2}{*}{ Variabel dan Atribut } & \multicolumn{2}{|c|}{ Status obesitas } & \multirow[t]{2}{*}{ Total } \\
\hline & Obesitas & $\begin{array}{c}\text { Tidak } \\
\text { obesitas }\end{array}$ & \\
\hline Tujuh Hari & 16.445 & 60.197 & 76.642 \\
\hline Total & 99.115 & 605.862 & 704.977 \\
\hline \multicolumn{4}{|l|}{ Makan Sayuran (X7) } \\
\hline Tidak Pernah & 1.211 & 8.496 & 9.707 \\
\hline Satu Hari & 2.967 & 21.273 & 24.240 \\
\hline Dua Hari & 4.614 & 32.626 & 37.240 \\
\hline Tiga Hari & 9.258 & 64.728 & 73.986 \\
\hline Empat Hari & 6.795 & 48.720 & 55.515 \\
\hline Lima Hari & 5.950 & 44.676 & 50.626 \\
\hline Enam Hari & 5.638 & 41.661 & 47.299 \\
\hline Tujuh Hari & 62.682 & 343.682 & 406.364 \\
\hline Total & 99.115 & 605.862 & 704.977 \\
\hline \multicolumn{4}{|l|}{ Makanan Manis (X8) } \\
\hline Kurang 1 kali per hari; & 21.493 & 137.827 & 159.320 \\
\hline Sekali per hari; & 30.645 & 180.807 & 211.452 \\
\hline 3 sampai 6 kali per minggu; & 16.332 & 105.750 & 122.082 \\
\hline 1 sampai 2 kali per minggu; & 18.617 & 114.371 & 132.988 \\
\hline Lebih dari 3 kali per bulan; & 6.972 & 40.536 & 47.508 \\
\hline Tidak pernah & 5.056 & 26.571 & 31.627 \\
\hline Total & 99.115 & 605.862 & 704.977 \\
\hline \multicolumn{4}{|l|}{ Makanan Asin (X9) } \\
\hline Kurang 1 kali per hari; & 7.092 & 49.085 & 56.177 \\
\hline Sekali per hari; & 12.687 & 83.881 & 96.568 \\
\hline 3 sampai 6 kali per minggu; & 17.513 & 3.619 & 131.132 \\
\hline 1 sampai 2 kali per minggu; & 29.693 & 185.251 & 214.944 \\
\hline Lebih 3 kali per bulan; & 21.019 & 114.322 & 135.341 \\
\hline Tidak pernah & 11.111 & 59.704 & 70.815 \\
\hline Total & 99.115 & 605.862 & 704.977 \\
\hline \multicolumn{4}{|l|}{ Makanan Berlemak (X10) } \\
\hline Kurang 1 kali per hari; & 14.416 & 77.542 & 91.958 \\
\hline Sekali per hari; & 22.307 & 120.775 & 143.082 \\
\hline 3 sampai 6 kali per minggu; & 23.162 & 140.589 & 163.751 \\
\hline 1 sampai 2 kali per minggu; & 26.786 & 172.629 & 199.415 \\
\hline Lebih 3 kali per bulan; & 9.875 & 73.996 & 83.871 \\
\hline Tidak pernah & 2.569 & 20.331 & 22.900 \\
\hline Total & 99.115 & 605.862 & 704.977 \\
\hline \multicolumn{4}{|l|}{ Stres (X11) } \\
\hline Tidak Stres & 88.269 & 24.712 & 34.958 \\
\hline Stres & 10.846 & 581.750 & 670.019 \\
\hline Total & 99.115 & 605.862 & 704.977 \\
\hline
\end{tabular}


Pada data asli obesitas RISKESDAS 2013 ini, data kelas minor adalah status obesitas, dan data kelas mayor adalah status tidak obesitas. Berdasarkan Tabel 1, data asli obesitas Survei RISKESDAS 2013 Indonesia yang mengalami ketidakseimbangan data kelas itu telah mengakibatkan amatan di kelas minor (obesitas) cenderung diabaikan dalam pengklasifikasian status obesitas. Oleh karena itu, permasalahan tersebut ditangani menggunakan teknik SMOTE dengan dua persentase berbeda yaitu $350 \%$ dan $600 \%$. Hal ini berarti bahwa data dikelas minor (obesitas) akan dibangkitkan sebesar masing-masing 3,5 kali dan 6 kali.

Tahapan selanjutnya adalah melakukan penghitungan jarak amatan dengan menggunakan MVDM untuk memperoleh jarak amatan seperti yang telah dijelaskan di bagian 2.3. Data pada kelas minor (obesitas) dipilih secara acak untuk menentukan 5 tetangga terdekat. Kemudian, kategori mayoritas yang terdapat pada vektor utama dan 5 tetangganya untuk variabel bersangkutan akan dipilih. Jika terjadi nilai yang sama, maka dipilih secara acak, dan nilai yang terpilih tersebut merupakan data sampel buatan yang baru.

Pada studi ini, SMOTE digunakan pada kelas data yang memiliki atau mempunyai kelipatan yang sama. Jika tidak, maka dilakukan penambahan atau pengurangan (penghapusan) data secara acak pada kelas mayor, yang mendekati kelipatan kelas minor. Kelas obesitas dan kelas tidak obesitas mempunyai kelipatan tidak sama.

Pada SMOTE dengan 350\% dibangkitkan data buatan sebesar 3,5 kali data minor sehingga diperoleh data baru sebanyak 346.902. Kemudian data baru ini ditambahkan pada data asli sehingga jumlah data baru yaitu 396.460. Jumlah data sebelum SMOTE adalah 99.115 dan setelah diterapkan SMOTE menjadi 396.460. Pada data hasil SMOTE dengan $350 \%$, perbandingan antara kelas mayor dan kelas minor adalah $40 \%$ pada kelas minor (obesitas) dan 60\% pada kelas mayor (tidak obesitas) (Tabel 3). Deskripsi data status obesitas RISKESDAS 2013 setelah diterapkan SMOTE dengan $350 \%$ dapat dilihat pada Tabel 4. Perbandingan kelas minor (obesitas) dan kelas mayor (tidak obesitas) dari setiap variabel tampak belum seimbang (Tabel 4).

Tabel 3: Hasil teknik SMOTE dengan $350 \%$ pada data obesitas RISKESDAS 2013

\begin{tabular}{lcc}
\hline Status Obesitas & Tanpa SMOTE & Persentase SMOTE 350\% \\
\hline Obesitas & $99.115(14,05 \%)$ & $396.460(40 \%)$ \\
Tidak obesitas & $605.862(85,95 \%)$ & $594.690(60 \%)$ \\
\hline Jumlah & $722.329(100 \%)$ & $991.150(100 \%)$ \\
\hline
\end{tabular}


Tabel 4: Deskripsi data obesitas RISKESDAS 2013 Menggunakan SMOTE dengan $350 \%$

\begin{tabular}{|c|c|c|c|}
\hline \multirow[b]{2}{*}{ Variabel dan Atribut } & \multicolumn{2}{|c|}{ Status obesitas } & \multirow[b]{2}{*}{ Total } \\
\hline & Obesitas & $\begin{array}{c}\text { Tidak } \\
\text { obesitas }\end{array}$ & \\
\hline \multicolumn{4}{|l|}{ Jenis kelamin (X1) } \\
\hline Laki-laki & 184.748 & 305.369 & 490.117 \\
\hline Perempuan & 211.712 & 289.321 & 501.033 \\
\hline Total & 396.460 & 594.690 & 991.150 \\
\hline \multicolumn{4}{|l|}{ Umur (X2) } \\
\hline 15 - 34 Tahun & 120.136 & 252.139 & 372.275 \\
\hline 35 - 54 Tahun & 188.971 & 227.390 & 416.361 \\
\hline 55 - 74 Tahun & 82.854 & 100.967 & 183.821 \\
\hline 75 - 94 Tahun & 4.486 & 13.974 & 18.460 \\
\hline 95 - 114 Tahun & 13 & 218 & 231 \\
\hline 115 - 134 Tahun & 0 & 2 & 2 \\
\hline Total & 396.460 & 594.690 & 991.150 \\
\hline \multicolumn{4}{|l|}{ Merokok (X3) } \\
\hline $\mathrm{Ya}$ & 165.238 & 199.081 & 364.319 \\
\hline Tidak & 231.222 & 395.609 & 626.831 \\
\hline Total & 396.460 & 594.690 & 991.150 \\
\hline \multicolumn{4}{|l|}{ Aktifitas berat (X4) } \\
\hline $\mathrm{Ya}$ & 177.219 & 241.373 & 418.592 \\
\hline Tidak & 219.241 & 353.317 & 572.558 \\
\hline Total & 396.460 & 594.690 & 991.150 \\
\hline \multicolumn{4}{|l|}{ Aktifitas sedang (X5) } \\
\hline Ya & 239.502 & 508.987 & 748.489 \\
\hline Tidak & 156.958 & 85.703 & 242.661 \\
\hline Total & 396.460 & 594.690 & 991.150 \\
\hline \multicolumn{4}{|l|}{ Makan buah (X6) } \\
\hline Tidak Pernah & 52.964 & 84.826 & 137.790 \\
\hline Satu Hari & 84.147 & 140.505 & 224.652 \\
\hline Dua Hari & 78.953 & 125.458 & 204.411 \\
\hline Tiga Hari & 77.622 & 116.377 & 193.999 \\
\hline Empat Hari & 30.108 & 40.647 & 70.755 \\
\hline Lima Hari & 14.779 & 19.827 & 34.606 \\
\hline Enam Hari & 6.135 & 7.962 & 14.097 \\
\hline Tujuh Hari & 51.752 & 59.088 & 11.0840 \\
\hline Total & 396.460 & 594.690 & 991.150 \\
\hline \multicolumn{4}{|l|}{ Makan sayuran (X7) } \\
\hline Tidak Pernah & 15.251 & 84.25 & 23.676 \\
\hline Satu Hari & 18.713 & 20.916 & 39.629 \\
\hline Dua Hari & 27.379 & 31.832 & 59.211 \\
\hline Tiga Hari & 58.663 & 63.334 & 121.997 \\
\hline
\end{tabular}




\begin{tabular}{|c|c|c|c|}
\hline \multirow[b]{2}{*}{ Variabel dan Atribut } & \multicolumn{2}{|c|}{ Status obesitas } & \multirow[b]{2}{*}{ Total } \\
\hline & Obesitas & $\begin{array}{c}\text { Tidak } \\
\text { obesitas }\end{array}$ & \\
\hline Empat Hari & 35.330 & 47.977 & 83.307 \\
\hline Lima Hari & 26.080 & 44.004 & 70.084 \\
\hline Enam Hari & 27.803 & 41.125 & 68.928 \\
\hline Tujuh Hari & 187.241 & 337.077 & 524.318 \\
\hline Total & 396.460 & 594.690 & 991.150 \\
\hline \multicolumn{4}{|l|}{ Makanan manis (X8) } \\
\hline Kurang 1 kali per hari; & 93.296 & 134.660 & 227.956 \\
\hline Sekali per hari; & 119.677 & 177.923 & 297.600 \\
\hline 3 sampai 6 kali per minggu; & 57.229 & 103.604 & 160.833 \\
\hline 1 sampai 2 kali per minggu; & 73.579 & 112.520 & 186.099 \\
\hline Lebih 3 kali per bulan; & 27.628 & 39.882 & 67.510 \\
\hline Tidak pernah & 25.051 & 26.101 & 51.152 \\
\hline Total & 396.460 & 594.690 & 991.150 \\
\hline \multicolumn{4}{|l|}{ Makanan asin (X9) } \\
\hline Kurang 1 kali per hari; & 33.300 & 47.890 & 81.190 \\
\hline Sekali per hari; & 49.129 & 82.058 & 131.187 \\
\hline 3 sampai 6 kali per minggu; & 70.098 & 112.010 & 182.108 \\
\hline 1 sampai 2 kali per minggu; & 109.483 & 181.311 & 290.794 \\
\hline Lebih 3 kali per bulan; & 80.438 & 112.543 & 192.981 \\
\hline Tidak pernah & 54.012 & 58.878 & 112.890 \\
\hline Total & 396.460 & 594.690 & 991.150 \\
\hline \multicolumn{4}{|l|}{ Makanan berlemak (X10) } \\
\hline Kurang 1 kali per hari; & 60.415 & 76.079 & 136.494 \\
\hline Sekali per hari; & 85.774 & 117.994 & 203.768 \\
\hline 3 sampai 6 kali per minggu; & 88.824 & 138.386 & 227.210 \\
\hline 1 sampai 2 kali per minggu; & 100.039 & 169.385 & 269.424 \\
\hline Lebih 3 kali per bulan; & 46.177 & 72.879 & 119.056 \\
\hline Tidak pernah & 15.231 & 19.967 & 35.198 \\
\hline Total & 396.460 & 594.690 & 991.150 \\
\hline \multicolumn{4}{|l|}{ Stress (X11) } \\
\hline Stres & 158.499 & 23.697 & 182.196 \\
\hline Tidak Stres & 237.961 & 570.993 & 808.954 \\
\hline Total & 396.460 & 594.690 & 991.150 \\
\hline
\end{tabular}

Selanjutnya penerapan teknik SMOTE dilakukan dengan menaikkan persentase ke over-sampling $600 \%$. Data buatan dibangkitkan sebesar 6 kali data minor menjadi 594.690, sehingga diperoleh data baru sebanyak 693.805. Jumlah data sebelum dan sesudah diterapkan SMOTE dengan 600\% adalah masing-masing 99.115 dan 693.805. Pada data hasil SMOTE dengan $600 \%$ ini, perbandingan antara kelas minor (obesitas) dan kelas mayor (tidak obesitas) menjadi nampak lebih seimbang yaitu $53,85 \%$ pada kelas obesitas dan $46,15 \%$ pada kelas tidak obesitas. Hasil teknik 
SMOTE dengan kenaikan persentase sampai $600 \%$ dapat dilihat pada Tabel 5 . Sebagai akibat, perbandingan kelas minor (obesitas) dan kelas mayor (tidak obesitas) dari setiap variabel terlihat seimbang (Tabel 6). Pada Tabel 5 disajikan gambaran data obesitas survei RISKESDAS 2013 Indonesia setelah dilakukan penyeimbangan data kelas berdasarkan variabel.

Tabel 5: Hasil teknik SMOTE dengan $600 \%$ pada data obesitas

RISKESDAS 2013

\begin{tabular}{lcc}
\hline Status Obesitas & Tanpa SMOTE & SMOTE 600\% \\
\hline Obesitas & $99.115(14,05 \%)$ & $693.805(53,84 \%)$ \\
Tidak obesitas & $605.862(85,95 \%)$ & $594.690(46,16 \%)$ \\
\hline Jumlah & $722.329(100 \%)$ & $1.288 .495(100 \%)$ \\
\hline
\end{tabular}

Tabel 6: Deskripsi data obesitas RISKESDAS 2013 Menggunakan SMOTE dengan $600 \%$

\begin{tabular}{|c|c|c|c|}
\hline \multirow[b]{2}{*}{ Variabel dan Atribut } & \multicolumn{2}{|c|}{ Status obesitas } & \multirow[b]{2}{*}{ Total } \\
\hline & Obesitas & $\begin{array}{c}\text { Tidak } \\
\text { obesitas }\end{array}$ & \\
\hline \multicolumn{4}{|l|}{ Jenis kelamin (X1) } \\
\hline Laki-laki & 335.315 & 305.448 & 640.763 \\
\hline Perempuan & 358.490 & 289.242 & 647.732 \\
\hline Total & 693.805 & 594.690 & 1.288 .495 \\
\hline \multicolumn{4}{|l|}{ Umur (X2) } \\
\hline 15 - 34 Tahun & 187.693 & 252.954 & 440.647 \\
\hline 35 - 54 Tahun & 316.288 & 227.106 & 543.394 \\
\hline 55 - 74 Tahun & 177.759 & 100.367 & 278.126 \\
\hline 75 - 94 Tahun & 12.040 & 14.025 & 26.065 \\
\hline 95 - 114 Tahun & 25 & 237 & 262 \\
\hline 115 - 134 Tahun & 0 & 1 & 1 \\
\hline Total & 693.805 & 594.690 & 128.8495 \\
\hline \multicolumn{4}{|l|}{ Merokok (X3) } \\
\hline Ya & 305.957 & 199.115 & 505.072 \\
\hline Tidak & 387.848 & 395.575 & 783.423 \\
\hline Total & 693.805 & 594.690 & 1.288 .495 \\
\hline \multicolumn{4}{|l|}{ Aktifitas berat (X4) } \\
\hline $\mathrm{Ya}$ & 316.295 & 241.303 & 557.598 \\
\hline Tidak & 377.510 & 353.387 & 730.897 \\
\hline Total & 693.805 & 594.690 & 1.288 .495 \\
\hline \multicolumn{4}{|l|}{ Aktifitas sedang (X5) } \\
\hline $\mathrm{Ya}$ & 395.439 & 509.174 & 904.613 \\
\hline Tidak & 298.366 & 85.516 & 383.882 \\
\hline Total & 693.805 & 594.690 & 1.288 .495 \\
\hline
\end{tabular}




\begin{tabular}{|c|c|c|c|}
\hline \multicolumn{4}{|l|}{ Makan buah (X6) } \\
\hline Tidak Pernah & 114.363 & 84.440 & 198.803 \\
\hline Satu Hari & 147.474 & 140.498 & 287.972 \\
\hline Dua Hari & 133.919 & 125.150 & 259.069 \\
\hline Tiga Hari & 132.543 & 116.989 & 249.532 \\
\hline Empat Hari & 43.621 & 40.494 & 84.115 \\
\hline Lima Hari & 24.695 & 19.811 & 44.506 \\
\hline Enam Hari & 8.194 & 7.900 & 16.094 \\
\hline Tujuh Hari & 88.996 & 59.408 & 148.404 \\
\hline Total & 693.805 & 594.690 & 1.288 .495 \\
\hline \multicolumn{4}{|l|}{ Makan sayuran (X7) } \\
\hline Tidak Pernah & 33.323 & 8.233 & 41.556 \\
\hline Satu Hari & 37.393 & 20.910 & 58.303 \\
\hline Dua Hari & 39.335 & 31.969 & 71.304 \\
\hline Tiga Hari & 122.558 & 63.891 & 186.449 \\
\hline Empat Hari & 64.058 & 48.056 & 112.114 \\
\hline Lima Hari & 40.333 & 43.814 & 84.147 \\
\hline Enam Hari & 43.566 & 41.092 & 84.658 \\
\hline Tujuh Hari & 313.239 & 336.725 & 649.964 \\
\hline Total & 693.805 & 594.690 & 1.288 .495 \\
\hline \multicolumn{4}{|l|}{ Makanan manis (X8) } \\
\hline Kurang 1 kali per hari; & 144.767 & 135.812 & 280.579 \\
\hline 1 kali per hari; & 190.085 & 177.015 & 367.100 \\
\hline 3 sampai 6 kali per minggu; & 95.066 & 104.132 & 199.198 \\
\hline 1 sampai 2 kali per minggu; & 149.148 & 111.596 & 260.744 \\
\hline Lebih 3 kali per bulan; & 61.202 & 39.969 & 101.171 \\
\hline Tidak pernah & 53.537 & 26.166 & 79.703 \\
\hline Total & 693.805 & 594.690 & 1.288 .495 \\
\hline \multicolumn{4}{|l|}{ Makanan asin (X9) } \\
\hline Kurang 1 kali per hari; & 47.452 & 48.041 & 95.493 \\
\hline Sekali per hari; & 91.010 & 82.599 & 173.609 \\
\hline 3 sampai 6 kali per minggu; & 119.109 & 111.737 & 230.846 \\
\hline 1 sampai 2 kali per minggu; & 186.465 & 181.915 & 368.380 \\
\hline Lebih 3 kali per bulan; & 139.576 & 112.015 & 251.591 \\
\hline Tidak pernah & 110.193 & 58.383 & 168.576 \\
\hline Total & 693.805 & 594.690 & 1.288 .495 \\
\hline \multicolumn{4}{|l|}{ Makanan berleman (X10) } \\
\hline Kurang 1 kali per hari; & 91.076 & 75.953 & 167.029 \\
\hline Sekali per hari; & 155.704 & 119.164 & 274.868 \\
\hline 3 sampai 6 kali per minggu; & 147.277 & 137.753 & 285.030 \\
\hline 1 sampai 2 kali per minggu; & 186.841 & 169.408 & 356.249 \\
\hline
\end{tabular}




\begin{tabular}{lccc}
\hline Lebih 3 kali per bulan; & 87.023 & 72.512 & 159.535 \\
Tidak pernah & 25.884 & 19.900 & 45.784 \\
\hline Total & 693.805 & 594.690 & 1.288 .495 \\
\hline Stres $(\mathrm{X} 11)$ & & & \\
Tidak Stres & 306.089 & 23.758 & 329.847 \\
Stres & 387.716 & 570.932 & 958.648 \\
\hline Total & 693.805 & 594.690 & 1.288 .495 \\
\hline
\end{tabular}

Tabel 7: Hasil teknik SMOTE dengan over-sampling $250 \%$ dan under-sampling 150\% pada data obesitas RISKESDAS 2013

\begin{tabular}{lcc}
\hline Status Obesitas & Tanpa SMOTE (\%) & $\begin{array}{c}\text { SMOTE over-sampling 250\% } \\
\text { dan under-sampling 150\% }(\%)\end{array}$ \\
\hline Obesitas & $99.115(14,05)$ & $297.345(50,00)$ \\
Tidak obesitas & $605.862(85,95)$ & $297.345(50,00)$ \\
\hline Jumlah & $722.329(100,00)$ & $594.690(100,00)$ \\
\hline
\end{tabular}

Modifikasi teknik SMOTE dengan kombinasi over-sampling dan under-sampling juga dilakukan yaitu over-sampling $250 \%$ dan under-sampling $150 \%$. Pada oversampling $250 \%$ dibangkitkan data buatan sebesar 2,5 kali data kelas minor sehingga diperoleh $247.787,5$ data baru. Kemudian data baru ini ditambahkan pada data asli yang hasilnya sebanyak 297.345. Jumlah data sebelum dan sesudah diterapkan SMOTE adalah masing 99.115 dan 297.345. Selanjutnya untuk under-sampling $150 \%$, data buatan dihapus sebesar 1.5 kali data mayor sehingga diperoleh 396.460 data baru. Data baru ini kemudian dikurangkan dengan jumlah data kelas minor sehingga diperoleh 297.345. Jumlah data sebelum dan sesudah diterapkan SMOTE adalah masing-masing 594.690 dan 297.345. Pada data hasil SMOTE ini, perbandingan antara kelas minor (obesitas) dan kelas mayor (tidak obesitas) menjadi lebih seimbang yaitu $50 \%$ pada kelas obesitas dan $50 \%$ pada kelas mayor (tidak obesitas). Hasil teknik SMOTE dengan kombinasi over-sampling $(250 \%)$ dan under-sampling $(150 \%)$ ini dapat dilihat pada Tabel 7. Tabel 8 menyajikan gambaran data obesitas Survei RISKESDAS 2013 Indonesia setelah dilakukan penyeimbangan data kelas berdasarkan variabel.

Dari Tabel 3, 5 dan 7 dapat dibandingkan jumlah kejadian obesitas dan tidak obesitas berdasarkan persentase teknik SMOTE (Tabel 9). Dari Tabel 9 diketahui bahwa teknik SMOTE dengan $600 \%$ dapat meningkatkan data kelas minor (obesitas) dengan lebih baik dan perbandingan kelas minor (obesitas) dan kelas mayor (tidak obesitas) menjadi mendekati seimbang. Sementara itu, teknik kombinasi oversampling dan under-sampling membuat dataset menjadi seimbang. 
Tabel 8: Deskripsi data obesitas RISKESDAS 2013 Menggunakan SMOTE dengan over-sampling $250 \%$ dan under-sampling $150 \%$

\begin{tabular}{|c|c|c|c|}
\hline \multirow[b]{2}{*}{ Variabel dan Atribut } & \multicolumn{2}{|c|}{ Status obesitas } & \multirow[b]{2}{*}{ Total } \\
\hline & Obesitas & $\begin{array}{c}\text { Tidak } \\
\text { obesitas }\end{array}$ & \\
\hline \multicolumn{4}{|l|}{ Jenis kelamin (X1) } \\
\hline Laki-laki & 134.150 & 152.599 & 286.749 \\
\hline Perempuan & 163.195 & 144.746 & 307.941 \\
\hline Total & 297.345 & 297.345 & 594.690 \\
\hline \multicolumn{4}{|l|}{ Umur (X2) } \\
\hline 15 - 34 Tahun & 88.321 & 126.689 & 215.010 \\
\hline 35 - 54 Tahun & 144.902 & 113.778 & 258.680 \\
\hline 55 - 74 Tahun & 60.846 & 49.767 & 110.613 \\
\hline 75 - 94 Tahun & 3.264 & 7.004 & 10.268 \\
\hline 95 - 114 Tahun & 12 & 104 & 116 \\
\hline 115 - 134 Tahun & 0 & 3 & 3 \\
\hline Total & 297.345 & 297.345 & 594.690 \\
\hline \multicolumn{4}{|l|}{ Merokok (X3) } \\
\hline Ya & 116.378 & 99.798 & 216.176 \\
\hline Tidak & 180.967 & 197.547 & 378514 \\
\hline Total & 297.345 & 297.345 & 594.690 \\
\hline \multicolumn{4}{|l|}{ Aktifitas berat $(\mathrm{X} 4)$} \\
\hline Ya & 128.258 & 120.694 & 248.952 \\
\hline Tidak & 169.087 & 176.651 & 345.738 \\
\hline Total & 297.345 & 297.345 & 594.690 \\
\hline \multicolumn{4}{|l|}{ Aktifitas sedang (X5) } \\
\hline Ya & 189.062 & 254.418 & 443.480 \\
\hline Tidak & 108.283 & 42.927 & 151.210 \\
\hline Total & 297.345 & 297.345 & 594.690 \\
\hline \multicolumn{4}{|l|}{ Makan Buah (X6) } \\
\hline Tidak Pernah & 38.869 & 42.513 & 81.382 \\
\hline Satu Hari & 62.347 & 70.158 & 132.505 \\
\hline Dua Hari & 58.926 & 62.318 & 121.244 \\
\hline Tiga Hari & 58.555 & 58.862 & 117.417 \\
\hline Empat Hari & 22.591 & 20.228 & 42.819 \\
\hline Lima Hari & 11.279 & 9.905 & 21.184 \\
\hline Enam Hari & 4.561 & 3.945 & 8.506 \\
\hline Tujuh Hari & 40.217 & 29.416 & 696.33 \\
\hline Total & 297.345 & 297.345 & 594.690 \\
\hline \multicolumn{4}{|l|}{ Makan sayuran (X7) } \\
\hline Tidak Pernah & 10.481 & 4.178 & 14.659 \\
\hline Satu Hari & 13.543 & 10.482 & 24.025 \\
\hline Dua Hari & 19.881 & 15.944 & 35.825 \\
\hline Tiga Hari & 42.164 & 31.865 & 74.029 \\
\hline
\end{tabular}




\begin{tabular}{|c|c|c|c|}
\hline \multirow[b]{2}{*}{ Variabel dan Atribut } & \multicolumn{2}{|c|}{ Status obesitas } & \multirow[b]{2}{*}{ Total } \\
\hline & Obesitas & $\begin{array}{c}\text { Tidak } \\
\text { obesitas }\end{array}$ & \\
\hline Empat Hari & 25.894 & 23.887 & 49.781 \\
\hline Lima Hari & 19.505 & 22.007 & 41.512 \\
\hline Enam Hari & 20.213 & 20.484 & 40.697 \\
\hline Tujuh Hari & 145.664 & 168.498 & 314.162 \\
\hline Total & 297.345 & 297.345 & 594.690 \\
\hline \multicolumn{4}{|l|}{ Makanan manis (X8) } \\
\hline Kurang 1 kali per hari; & 69.214 & 67.416 & 136.630 \\
\hline Sekali per hari; & 89.943 & 88.838 & 178.781 \\
\hline 3 sampai 6 kali per minggu; & 43.620 & 52.056 & 95.676 \\
\hline 1 sampai 2 kali per minggu; & 55.583 & 55.959 & 111.542 \\
\hline Lebih 3 kali per bulan; & 20.678 & 19.886 & 40.564 \\
\hline Tidak pernah & 18.307 & 13.190 & 31.497 \\
\hline Total & 297.345 & 297.345 & 594.690 \\
\hline \multicolumn{4}{|l|}{ Makanan asin (X9) } \\
\hline Kurang 1 kali per hari; & 24.675 & 24.043 & 48.718 \\
\hline Sekali per hari; & 37.044 & 41.306 & 78.350 \\
\hline 3 sampai 6 kali per minggu; & 52.626 & 55.740 & 108.366 \\
\hline 1 sampai 2 kali per minggu; & 82.729 & 90.731 & 173.460 \\
\hline Lebih 3 kali per bulan; & 60.456 & 56.378 & 116.834 \\
\hline Tidak pernah & 39.815 & 29.147 & 68.962 \\
\hline Total & 297.345 & 297.345 & 594.690 \\
\hline \multicolumn{4}{|l|}{ Makanan berlemak (X10) } \\
\hline Kurang 1 kali per hari; & 45.043 & 38.097 & 83.140 \\
\hline Sekali per hari; & 64.436 & 58.973 & 123.409 \\
\hline 3 sampai 6 kali per minggu; & 66.766 & 69.247 & 136.013 \\
\hline 1 sampai 2 kali per minggu; & 76.011 & 84.965 & 160.976 \\
\hline Lebih 3 kali per bulan; & 34.096 & 36.153 & 70.249 \\
\hline Tidak pernah & 10.993 & 9.910 & 20.903 \\
\hline Total & 297.345 & 297.345 & 594.690 \\
\hline \multicolumn{4}{|l|}{ Stres (X11) } \\
\hline Stres & 109.116 & 11.901 & 121.017 \\
\hline Tidak Stres & 188.229 & 285.444 & 473.673 \\
\hline Total & 297.345 & 297.345 & 594.690 \\
\hline
\end{tabular}


Tabel 9: Jumlah kejadian obesitas dan tidak obesitas berdasarkan persentase teknik SMOTE.

\begin{tabular}{lcc}
\hline \multicolumn{1}{c}{$\begin{array}{c}\text { Persentase Teknik } \\
\text { sampling (\%) }\end{array}$} & $\begin{array}{c}\text { Kelas Tidak } \\
\text { obesitas }\end{array}$ & Kelas Obesitas \\
\hline SMOTE Over-sampling 350 & 594.690 & 396.460 \\
SMOTE Over-sampling 600 & 594.690 & 693.805 \\
Over-sampling 250\%, & 297.345 & 297.345 \\
under sampling 150\% & & \\
\hline
\end{tabular}

\section{Simpulan}

Eksplorasi status obesitas dari survei RISKESDAS 2013 Indonesia telah dilakukan dengan menggunakan teknik tanpa SMOTE, teknik SMOTE dan teknik kombinasi over-sampling dan under-sampling. Hasilnya menunjukkan jumlah kelas obesitas dan tidak obesitas mengalami ketidakseimbangan kelas data dengan kriteria sedang. Ketidakseimbangan kelas data ini telah di atasi dengan teknik SMOTE dan teknik oversampling dan under-sampling. Pada penggunaan teknik over-sampling dan undersampling dataset kelas obesitas dapat dibuat seimbang dengan mudah. Namun, oversampling pada dataset kelas minoritas (obesitas) menuju pada hasil yang overfitting. Sementara teknik SMOTE dengan 600\% dapat meningkatkan data kelas minor (obesitas) dengan lebih baik. Dalam studi yang akan datang, hasil yang telah diperoleh ini akan divalidasi dengan metode mengatasi ketidakseimbangan data lainnya dan prediksi kinerja metode klasifikasi pembelajaran mesin.

Ucapan Terima Kasih. Penulis pertama berterima kasih kepada Kementerian Riset dan Teknologi/ Badan Riset dan Inovasi Nasional yang telah membiayai studi ini melalui Skema PDUPT tahun anggaran 2020 nomor kontrak 1516/UN4.22/PT.01.03/2020. Selain itu penulis pertama juga mengucapkan terima kasih kepada Kementerian Kesehatan melalui Badan Penelitian dan Pengembangan Masyarakat yang telah memberikan akses ke data RISKESDAS Indonesia.

\section{Daftar Pustaka}

Alghamdi, M., Al-Mallah, M., Keteyian, S., Brawner, C., Ehrman, J., \& Sakr, S. (2017). Predicting diabetes mellitus using SMOTE and ensemble machine learning approach: The Henry Ford Exerclse Testing (FIT) project. PLOS ONE, 12(7): e0179805.

ASEAN / UNICEF / WHO Regional Report. (2016). World health statistics 2016: monitoring health for the SDGs, sustainable development goals.

Branco, P., Torgo, L., \& Ribeiro, R. P. (2016). A Survey of Predictive Modeling on Imbalanced Domains. ACM Comput. Surv., 49(2). https://doi.org/10.1145/2907070 
Chawla, N. V. (2005). Data Mining for Imbalanced Datasets: An Overview. In O. Maimon \& L. Rokach (Eds.), Data Mining and Knowledge Discovery Handbook (pp. 853-867). https://doi.org/10.1007/0-387-25465-X_40

Chawla, N. V., Bowyer, K. W., Hall, L. O., \& Kegelmeyer, W. P. (2002). SMOTE: Synthetic Minority Over-sampling Technique. Journal of Artificial Intelligence Research, 16: 321-357. https://doi.org/10.1613/jair.953

Chen, X., \& Wasikowski, M. (2008). FAST: A Roc-Based Feature Selection Metric for Small Samples and Imbalanced Data Classification Problems. Proceedings of the 14th ACM SIGKDD International Conference on Knowledge Discovery and Data Mining, 124-132. https://doi.org/10.1145/1401890.1401910

Cost, S., \& Salzberg, S. (1993). A Weighted Nearest Neighbor Algorithm for Learning with Symbolic Features. Machine Learning, 10(1): 57-78. https://doi.org/10.1023/A:1022664626993

Ente, D. R., Thamrin, S. A., Arifin, S., Kuswanto, H., \& Andreza, A. (2020). Klasifikasi Faktor-Faktor Penyebab Penyakit Diabetes Melitus Di Rumah Sakit Unhas Menggunakan Algoritma C4.5. Indonesian Journal of Statistics and Its Applications, 4(1): 80-88. https://doi.org/10.29244/ijsa.v4i1.330

Jo, T., \& Japkowicz, N. (2004). Class Imbalances versus Small Disjuncts. SIGKDD Explor. Newsl., 6(1): 40-49. https://doi.org/10.1145/1007730.1007737

[KEMENKES RI], Kementerian Kesehatan Republik Indonesia. (2014). Profil Kesehatan Indonesia Tahun 2013. Jakarta (ID): Kemenkes RI.

Krawczyk, B. (2016). Learning from imbalanced data: open challenges and future directions. Progress in Artificial Intelligence, 5(4): 221-232. https://doi.org/10.1007/s13748-016-0094-0

Mustaqim, M., Warsito, B., \& Surarso, B. (2019). Kombinasi Synthetic Minority Oversampling Technique (SMOTE) dan Neural Network Backpropagation untuk menangani data tidak seimbang pada prediksi pemakaian alat kontrasepsi implan. Register: Jurnal IImiah Teknologi Sistem Informasi, 5(2): 116-127. https://doi.org/10.26594/register.v5i2.1705

[RISKESDAS], Riset Kesehatan Dasar. (2013). Hasil Riset Kesehatan Dasar 2013. Jakarta (ID): Kemenkes RI.

Selya, A. S., \& Anshutz, D. (2018). Machine learning for the classification of obesity from dietary and physical activity patterns. In Advanced Data Analytics in Health (pp. 77-97). Springer.

Sun, Y., Wong, A. K. C., \& Kamel, M. S. (2009). Classification of Imbalanced data: a review. International Journal of Pattern Recognition and Artificial Intelligence, 23(4): 687-719. https://doi.org/10.1142/S0218001409007326

Witten, I. H., Frank, E., \& Hall, M. A. (2011). Data mining: practical machine learning tools and techniques (3rd ed.). https://doi.org/10.1016/C2009-0-19715-5 
Yap, B. W., Rani, K. A., Rahman, H. A. A., Fong, S., Khairudin, Z., \& Abdullah, N. N. (2014). An Application of Oversampling, Undersampling, Bagging and Boosting in Handling Imbalanced Datasets. In T. Herawan, M. Deris, \& J. Abawajy (Eds.), Proceedings of the First International Conference on Advanced Data and Information Engineering (DaEng-2013) (pp. 13-22). https://doi.org/10.1007/978981-4585-18-7_2

Zhang, D., Liu, W., Gong, X., \& Jin, H. (2011). A Novel Improved SMOTE Resampling Algorithm Based on Fractal. Computational Information Systems, 2204-2211.

Zhu, T., Lin, Y., \& Liu, Y. (2017). Synthetic Minority Oversampling Technique for Multiclass Imbalance Problems. Pattern Recogn., 72(C): 327-340. https://doi.org/10.1016/j.patcog.2017.07.024 